Platskamp, specialnummer av

Arkiv. Tidskrift för sambällsanalys, nr 9 (2018)

\title{
Att göra kaos. Om förortspolitiken som urban styrregim och demokratiskt spel
}

\section{Nazem Tahvilzadeh \& Lisa Kings}

SAMMANDRAG: I Nazem Tahvilzadeh och Lisa Kings artikel diskuteras orsakerna till den uppståndelse, eller "kaos" för att använda aktivisternas egna ord, som organisationen Megafonen skapade inom ramen för stadsutvecklingsprojektet Järvalyftet i Husby. Med inspiration från teorier om hur samtycke till ojämlikhet grundläggs på fabriksgolvet utvecklas två begrepp för att synliggöra den politiska ordningen i förorten och dess konkreta aktiviteter: urbana styrregimer och demokratiska spel. Studien visar hur Megafonens avhopp och sedermera kritik av Järvalyftet och förortspolitiken bröt mot den etablerade politiska ordningen i relationerna mellan stat och civilsamhälle i den urbana periferin. Aktivisternas handlingar kom därför att betraktas som "skandalösa" av delar av det politiska etablissemanget. Megafonen vägrade att spela enligt spelets regler och synliggjorde således ojämlikheterna i förortspolitikens demokratiska spel med medborgarna. Underlaget för studien baseras på processpårande och etnografisk metod som empiriskt återskapar den förortspolitiska satsningen Järvalyftet och dess logiker samt Megafonens roll 2006-2013.

NYCKELORD: segregation; förorten; sociala rörelser; Husby; Järvalyftet; Megafonen; civilsamhälle.

PUBLICERINGSHISTORIK: Originalpublicering.

NAZEM TAHVilzadeh är forskare vid Kungliga Tekniska högskolan.

E-POSTADRESS: nazem.tahvilzadeh@abe.kth.se

LISA KINGS är lektor i socialt arbete vid Södertörns högskola.

E-POSTADREss: lisa.kings@sh.se

FÖRSLAG PÅ KÄLLANGIVELSE:

Tahvilzadeh, Nazem \& Lisa Kings (20I8) "Att göra kaos. Om förortspolitiken som urban styrregim och demokratiskt spel”, i Platskamp, specialnummer av Arkiv. Tidskrift för samhällsanalys, nr 9, s. I03-128.

DOI: https://doi.org/IO.I3068/2000-6217.9.4

(C) Författarna/Arkiv förlag \& tidskrift 2018 (publicerad 28 maj 20I8)

Artikeln distribueras enligt en upphovsrättslicens från Creative Commons: Erkännande-Ickekommersiell-IngaBearbetningar 3.0 Unported, som medger fri ickekommersiell användning och spridning i oförändrat skick så länge källan anges. 
Arkiv. Tidskrift för samhällsanalys är en sakkunniggranskad vetenskaplig tidskrift för samhällsvetenskap och historia. Samtliga artiklar publiceras fritt tillgängliga på:

$$
\text { www.tidskriftenarkiv.se }
$$

Beständig länk, DOI: https://doi.org/IO.I3068/2000-62I7

Den här artikeln finns tillgänglig i följande format:

PDF: via beständig länk, DoI: https://doi.org/IO.I3068/2000-62I7.9.4

TRYCK: ingår i bokutgåva av numret, ISBN: 978 9I 79243159

Grafisk utformning och sidnumrering är identisk i pdf och tryck.

Samtliga artiklar i nr 9 (2018), Platskamp, nås via beständig länk, DOI: https://doi.org/I0.I3068/2000-6217.9

Redaktion för nUmret: Magnus Dahlstedt, Lisa Kings \& Nazem Tahvilzadeh

Arkiv. Tidskrift för sambällsanalys

ISSN: 2000-62I7 (för elektronisk resurs)

ISSN: 2000-6225 (för tryckta nummer)

ges ut av

Stiftelsen Arkiv för främjande och spridning av samhällsvetenskaplig och historisk forskning

genom

Arkiv förlag \& tidskrift

Box 1559

SE-22I OI Lund

BESÖK: L Gråbrödersg 3 c, ipg

TEL: 046-I3 3920

ARKIV FÖRLAG: arkiv@arkiv.nu·www.arkiv.nu

TIDSKRIFTEN ARKIV: red@tidskriftenarkiv.se.www.tidskriftenarkiv.se

ANSVARIg UTGIVARE \& CHEFREDAKTÖR: Sven Hort

AdMinistrativ Redaktör: David Lindberg

Redaktörer: Paavo Bergman, Per Dannefjord, Lisa Kings,

Zhanna Kravchenko, Anna-Maria Sarstrand Marekovic 


\title{
Att göra kaos. \\ Om förortspolitiken som urban styrregim och demokratiskt spel
}

\author{
NAZEM TAHVILZADEH \& LISA KINGS
}

Vi fick alltid känslan av att de så gärna ville se oss hetsa, bränna, kasta. Så att vi kunde avfärdas som ännu ett förortsgäng som egentligen inte intresserar sig för politik utan bara vill ställa till med kaos. [...] Som att demokrati skulle vara olaglig beroende på vem som utövar det. (Abdul Fattah 20I4.)

Megafonen är en av flera organisationer i förortsrörelsen som på senare tid skapat stor uppståndelse. I citatet ovan kritiserar socialpedagogen och aktivisten Nabila Abdul Fattah politikers och myndighetspersoners demoniseriering av Megafonen, och i synnerhet att de betraktas som odemokratiska eftersom de förväntas vara ett "förortsgäng" som ska "ställa till med kaos". Abdul Fattah var en av initiativtagarna till protestkampanjen Alby är inte till salu, som sedan blev en del av Megafonen. Hon beskriver en känsla som vid tidpunkten delades av de andra aktivisterna. Megafonen hade redan tidigare hamnat i den mediala hetluften för att inte ha tagit avstånd från våldet under upploppen i Husby 2013. Vissa menade till och med att individer i organisationen hade orsakat de omskrivna kravallerna ( $D N_{4}$ juni 20I3; Aftonbladet I4 maj 20I4). Att de ifrågasattes av delar av offentligheten var dock i samband med upploppen ingenting nytt. ${ }^{I}$ Misstänkliggörandet av Megafonen uppstod redan lokalt i Stockholm några år tidigare, där de unga aktivisternas handlingar gjort dem ytterst kontroversiella.

I. Det finns oss veterligen inga åtal eller domar som bekräftar att medlemmar $i$ Megafonen eller Alby är inte till salu deltagit i upplopp eller andra våldsamma handlingar riktade mot individer eller organisationer. 
Det hela startade med att Megafonen valde att avbryta ett samarbete inom ramen för det lokala förnyelseprojektet Järvalyftet. Efter att ha upplevt att deras engagemang och arbete inte respekterades, valde de att ställa sig utanför för att kunna arbeta för social mobilisering och politiskt påverkansarbete. Att vara "megafonare" kom i Husby och andra stadsdelar att innebära någonting radikalt nytt: ett politiskt ställningstagande kring "orten" som identitet och plattform för en kritisk och oberoende organisation som kämpar för förändring i konflikt med den lokala staten. Reaktionen från stadens myndigheter blev dock repressiv: de unga aktivisterna exkluderades och deras verksamhet ifrågasattes. I denna artikel frågar vi oss hur det var möjligt att en handfull unga aktivisters avhopp från och kritik av ett kommunalt stadsutvecklingsprojekt kunde åstadkomma sådan turbulens, eller "kaos" för att använda deras egna ord, bara genom ganska traditionellt arbete för politisk mobilisering och opinionsbildning? Vidare och satt i ett större perspektiv är vårt syfte att skapa djupare förståelse för den politiska ordning som präglar relationen mellan civilsamhälle och stat i den urbana periferin.

Vårt empiriska material omfattar Megafonens omvandlingsprocess och hur medlemmarna uppfattat det offentliga bemötandet, från att de var ett litet kompisgäng i Husby till att de blev en del av en framväxande urban rörelse. I denna studie placerar vi ungdomarnas agerande inom ramen för en politisk ordning som etablerats i förorter i syfte att ordna relationer mellan stat och civilsamhälle. Vi diskuterar i synnerhet hur förortspolitikens områdesavgränsade projekt bidrar till att forma det vi kallar för "urbana styrregimer" som genom "demokratiska spel” engagerar förortsbornas att delta och kalibrerar deras aktiviteter så att de blir samförståndsinriktade. Vi menar att denna ordning skapar få förutsättningar för kritiska röster i den urbana periferin. Det som Megafonen kallar kaos, den uppståndelse som följde av att de valde att hoppa av ett kommunalt utvecklingsprojekt, kan förklaras utifrån att de utfört en handling som stökat till en förment demokratisk politisk ordning (Young 2000). Det "skandalösa" (jfr Eduards 2002) i Megafonens handlingar kan således förstås mot bakgrund av deras artikulerande av krav på deltagande i ett sammanhang där demokratisering utlovats, men där ungdomarna i själva verket exkluderats. Exkluderingen 
berodde endast på att de anammat kritiska förhållningssätt i relation till förortspolitiken.

I det följande kommer vi att diskutera de centrala begreppen för vår analys och motivera hur maktrelationer på fabriksgolvet, som är vår huvudsakliga begreppsliga referensram genom Michael Burawoys (I979; 1985; 20I2) analyser av hur konflikter hanteras på fabriker, kan göra sig gällande i en marginaliserad stadsdel. Genom en etnografisk och processpårande metodologi återges sedan berättelsen om Megafonens tillblivelse och "skandalösa handlingar" i relation till den förortspolitiska satsningen "Järvalyftet".

\section{Deltagande och mystifiering: från fabrik till stadsdel}

Förortens befolkning har genom åren varit föremål för en rad statliga utvecklingsprojekt samt antisegregations- och demokratisatsningar (Urban 20I8, kap. 4). Motiven är bland annat att motverka segregation, förbättra levnadsvillkor, skapa samverkan med civilsamhället och uppmuntra befolkningen att delta mer i den representativa demokratins etablerade kanaler som val, partier och andra deltagandeforum (Tahvilzadeh 2015). Men det förortspolitiska imperativet att "aktivera förorten" (Dahlstedt 2009) har varken haft demokratiserande effekter eller resulterat i bättre levnadsvillkor. Tvärtom har situationen i städerna blivit mer ojämlik (exempelvis Stockholms stad 2015a) trots att förortsborna deltar så mycket som de faktiskt gör i olika samverkansprojekt (Kugelberg \& Trovalla 20I5). Förortspolitiken har kritiserats för bristande måluppfyllelse och utvärderingar har konstaterat att verksamheten är "misslyckad" förutom när det gäller att skapa resurser och nyttor till enskilda samt att förmildra de värsta konsekvenserna av ojämlikheter i staden (Urban 20I8; Olsson \& Törnquist 2009). Även om förortspolitiken inte har lyckats bryta segregationen är det relevant att resonera kring dess direkta och indirekta funktioner i andra avseenden.

Trots ett flertal utvärderingar av förortspolitiken finns fortfarande få studier som bidrar med perspektiv som frångår policymålens inneboende logiker, det vill säga att politiken syftar till att bryta segregationen. Undantaget är kritiska analyser inspirerade av foucauldianska 
perspektiv som framför att dessa demokratisatsningar kan ses som en form av ideologisk manipulering som formar deltagarnas subjektiviteter utefter andra logiker. Magnus Dahlstedt (2009, s. 193) menar exempelvis att förortspolitiska styrtekniker idealiserar medborgare som ett "aktivt, ansvarstagande, pragmatiskt, men samtidigt konfliktundvikande subjekt”. Samverkansprojekt öppnar för deltagande men stänger samtidigt ner möjligheterna att ifrågasätta dess villkor eftersom medborgaren gör "partnerskapets problemformuleringar och målsättningar till sina egna” (ibid., s. 193). Vi instämmer i utgångspunkten att staten försöker kontrollera och tillrättalägga civilsamhällets aktiviteter i led med egna logiker, men från vår horisont kan detta perspektiv vidareutvecklas. En utmaning för subjektsförvrängande ideologisk manipulering är de facto svårigheter att hantera situationer då det krävs mer av den lokala staten för att hantera motstånd och oföljsamhet. I det fall vi ska studera uppstår en sådan situation när en organisation väljer att hoppa av ett dialogprojekt och i stället börjar kritisera projektets övergripande logiker. I relation till föreliggande studie är det centralt att förstå eventuella manipulativa drag i förortspolitiken som ofullkomliga och försöka förklara hur statliga operationer ändå kan nå ett visst resultat genom en mångfald av styrtekniker.

Walter J. Nicholls och Justus Uitermark (2017, s. 33) bidrar utifrån vårt perspektiv med värdefulla insikter. De visar att marginaliserade gruppers urbana rörelser manipuleras genom statliga insatser för att "politiskt integrera" avvikande och riskfyllda element i civilsamhället (jfr Nicholls 2003). Förortens perifera position i den urbana hierarkin gör den på så sätt till en plats för potentiell konflikt, vilket bland annat förekomsten av spontana upplopp indikerar (Mayer m.fl. 20I6). Att med statlig styrning påverka det civila samhället syftar därför till att skapa önskad social och politisk ordning (Dikec 2007). Men hur går staten konkret till väga för att styra civilsamhällets aktiviteter utefter egna målsättningar? Om denna styrning inte endast sker genom ideologisk förvrängning av subjektiviteter som foucauldianska perspektiv föreslår, behövs alternativa perspektiv som kan öka förståelsen för relationen mellan stat och civilsamhälle i den urbana periferin. För att vidareutveckla förståelsen av detta fenomen utgår vi från Michael Burawoys (1979; 1985; 2012) teori om hur konflikter 
mellan olika grupper och klasser hanteras på organisations- och individnivå med fabriksgolvet som politiskt mikrokosmos.

Även om relationerna i stadens grannskap inte kan likställas med dem på fabriksgolvet behandlar Burawoy två centrala frågeställningar som är relevanta i det här sammanhanget. För det första problematiserar han managementteorins fokus på hur det kommer sig att arbetare inte arbetar mer effektivt och frågar i stället hur det kommer sig att arbetare över huvud taget är motiverade att arbeta så hårt som de gör. För det andra menar Burawoy att framgångsrik ideologisk manipulering inte endast sker genom uppfostran, skola eller annan tankekontroll. Hans utgångspunkt är att arbetarnas samtycke till sin egen exploatering grundas genom att arbetsgivaren utnyttjar deras intressedrivna beteende och ordnar konkreta aktiviteter på fabriksgolvet. Vi kan dra liknande paralleller mellan fabriken och stadsdelen med Burawoys idéer som utgångspunkt. Det är mycket vanligare att i forskning om förorten utgå från att förortsborna inte deltar i politik och att de inte är engagerade i samhället, i stället för att undersöka vad deras deltagande och engagemang faktiskt utmynnar i. I det följande kommer vi att undersöka ett fall där en öppen konflikt mellan deltagandemotiverade förortsbor och statens styrning uppstår för att diskutera den politiska ordning som ramar in deltagandet. Vi börjar med Burawoys centrala idéer om maktrelationerna på fabriksgolvet innan vi övergår till staden som mikrokosmos för konflikthantering.

\section{Styrregimer och ackordsspel på fabriksgolvet}

För Burawoy är de sociopolitiska relationerna i fabriken inte konfliktfria utan tvärtom historiskt återkommande, där fabriksägare och ledning å ena sidan och arbetarkollektivet å den andra kämpar för sina respektive intressen. Arbetarnas organisering stärker förhandlingsförmågan gentemot fabriksledningen, som dominerar arbetarnas deltagande i produktionen i egenskap av ägare av produktionsmedlen. Över tid institutionaliseras intressemotsättningarna i ideologiska och politiska procedurer för konflikthantering. Burawoy menar att detta bidrar till att upprätta vissa normer på fabriksgolvet. För det första etableras i varje fabrik särskilda "styrregimer" som reglerar procedurer för klagomålshantering och 
förhandling. För det andra fungerar ett "ackordsspel" som en norm i arbetsprocessens mikrorelationer.

Burawoy frågar sig under fältstudier på det löpande bandet varför han riskerar liv och lem på sin arbetsstation för att få lite mer i lön? Svaret är att han spelade med i spelet. Genom ackordsspelet kan den enskilda individen vinna eller förlora provision i relation till egna prestationer. Utmaningen handlar dels om att lära sig hur uppgifterna på en arbetsstation mest effektivt genomförs utifrån mått som fabriksledningen uppställt. Ytterligare utmaningar består i att bemanna de mest gynnsamma arbetsstationerna och behålla fördelaktiga prestationsnivåer. Spelet ger enligt Burawoy (I992, s. IO5) arbetare en "relativ tillfredsställelse"; tiden går snabbare och ger individen möjlighet att uthärda tristess och monotona ansträngningar. Förmännen utövar inte ett direkt tvång och arbetarna beter sig inte heller som hjärntvättade subjekt. Spelet fungerar dock som en effektiv norm för att organisera vardagen i linje med fabriksledningens intressen. Spelet bidrar enligt Burawoy till att skapa ett spontant samtycke och relativ harmoni mellan två parter med olika intressen.

Genom att delta i spelet kan den enskilda arbetaren nämligen utifrån egna prestationer avancera i hierarkin och vinna de mest fördelaktiga arbetsstationerna. Samtidigt mystifieras och säkerställs maktrelationerna i arbetsprocessen eftersom arbetarens fokus är inställt på att konkurrera med andra om fördelar och prestige, inte på de ojämlika villkoren. Genom styrregimen och ackordsspelet omvandlas den enskilda arbetaren till en "industriell medborgare" snarare än medlem av en klass med gemensamma intressen, skriver Burawoy: "Spelet avspeglar inte någon bakomliggande intresseharmoni; det är tvärtom orsaken till att denna harmoni uppkommer" (I992, s. I08). Slutsatsen som vi tar med oss är följande: Spelet ger sämre möjligheter för kollektiv handling bland arbetare och utnyttjar individernas rationella intressen genom att uppmuntra till inbördes konkurrens. Arbetarna tenderar att spela spelet och eftersträva individuella fördelar hellre än att ifrågasätta spelets regler. 


\section{Urbana styrregimer och demokratiska spel i förorten}

Stadsdelen är liksom fabriksgolvet ett mikrokosmos för konflikter även om relationerna är mer svåravgränsade. Kritisk urbanteori har etablerat en förståelse av de sociala relationerna i stadens vardagsliv som en andra konfliktlinje utöver den mellan arbete och kapital i industrins mikrokosmos (Lefebvre 1991; Harvey 1976). Men i staden blir en tredje aktör central då den lokala staten i regel agerar som mellanhand och konflikthanterare. Specifikt handlar det om reglering och utbud av samt tillgång till "kollektiv konsumtion" (Castells 1977) - det vill säga offentlig service som invånarna är beroende av för att kunna fungera som effektiv arbetskraft, så som bostäder, transporter, utbildning, välfärd och rekreation. Denna service möter medborgarna till stor del genom den lokala statens beslut och serviceproduktion. Vägar och skolor finansieras av gemensamma skattemedel, bostäder och kollektivtrafik med privatfinansierade hyror och biljettförsäljning. Eftersom det inte finns ett konstitutionellt imperativ för exakt hur bra arbetares livskvalitet ska vara, blir det en fråga om förhandling mellan den lokala staten och invånarna (Cockburn 1977). Då stadens boendemiljöer tenderar att ordnas utefter klassamhällets hierarkier, uppträder klasskonflikter även som platskamper där boende i de mest utsatta och förtryckta stadsdelarna organiserar sig för att framföra sina besvär och krav till fastighetsägarna och den lokala staten. Kampen om den kollektiva konsumtionen föranleder därför statliga strategier för konflikthantering, särskilt mot bakgrund av samtida åtstramningspolitik.

Över tid har det därför formats distinkta styrsystem för att reglera relationer mellan staten och det civila samhället i stadens "riskzoner", där befolkningen har mest anledning att ifrågasätta serviceproduktion och livskvalitet. Vi benämner dessa politiska procedurer för den lokala klagomålshanteringen som "urbana styrregimer". Vi avgränsar formeringen av denna regim till ett policyområde trots att det över tid givetvis har påverkats av andra. Vi menar att dessa regimer formas av den så kallade förortspolitiken, alltså offentligt initierade, ad hoc-organiserade och områdesbaserade förnyelseprojekt riktade till ett allt större antal förorter sedan 1980-talet (Urban 20I8). Sett över tid utgör regimen en permanent politik men utgörs alltså i dess operationer av tidsbegränsade 
projekt. Begreppet urbana regimer används i regel för att synliggöra hur städers makthavare prioriterar samverkan med dominerande aktörer i informella eller formella styrkoalitioner, samt hur stadens övergripande agenda formas och vilka politiska frågor som hamnar i centrum (Stone 1989; Franzén m.fl. 2016, s. 36-39). Vi använder dock urbana styrregimer i led med Burawoy för att fånga hur den lokala staten, genom och inom ramen för olika projekt, upprättar en politisk ordning för klagomålshantering med civilsamhället i syfte att neutralisera konflikter utan att förändra den urbana maktordningen.

Vårt regimbegrepp är därför lokalt avgränsat till stadsdelsnivå och kan ingå som bestående del i olika urbana regimer, till exempel "entreprenörsurbanismen" (Franzén m.fl. 2016). Genom att dra nytta av individers rationella intressedrivna aktiviteter integrerar staten det civila samhället i styrningen utan att förändra politikens innehåll. Det vi benämner som urbana styrregimer omfattar många direktiv med olika intentioner. Dessa kan dock inte förstås isolerade utan måste placeras in i en historisk förortspolitisk kontext som över tid och efter en rad upprepade projektsatsningar fått ett visst resultat. Detta betyder inte att projekten vart och ett för sig eller de tjänstepersoner och politiker som verkar för dessa policyprogram identifierar sig med eller aktivt verkar för att upprätthålla de urbana styrregimerna. Vi vill understryka att det inte är regimer i sig som ansvarar för den ojämlika samhällsutvecklingen. Regimer och spel utgör dock en funktion i relation till ojämlik samhällsutveckling. Låt oss förklara detta utförligare.

I en vardag där en relativt stor del av invånarna saknar arbete eller har en utsatt position på arbetsmarknaden, saknar grundläggande språkkunskaper i svenska eller tillgång till kvalitativ samhällsservice så som skolor, vård eller detaljhandel, fungerar det traditionella föreningslivet i den urbana periferin som ett sätt att lösa gemensamma problem där det privata eller offentliga inte räcker till (Kings 20II). Det faktum att det civila samhället blir mer organiserat kring sociala verksamheter och olika typer av serviceproduktion är inte något som är avgränsat till den urbana periferin. Civilsamhällets förskjutning från röst- och idébärande till serviceproduktion är en generell trend i samhället (Wijkström \& Lundström 2002). I den urbana periferin har förskjutningen dock fått en 
särskild riktning och intensitet utifrån behov men också särskilt genom förortspolitiken, som utlovat social och fysisk förnyelse genom projektbaserad samverkan med civilsamhället. Konkret har dessa demokratiska spel fungerat som ett sätt att engagera och uppmuntra medborgare och föreningar till ökat ansvarstagande och delaktighet. De resurser och det inflytande över den politiska agendan som skulle krävas för att på ett betydelsefullt och långsiktigt sätt förbättra befolkningens livskvalitet delegeras dock inte till dessa projekt. Projekten kan till exempel inte lösa arbetslösheten på egen hand. Deltagandet i projekten kan dock resultera i personliga förmåner för deltagarna (Gustafson \& Hertting 20I7). Genom förortspolitiken engageras därför befolkningen i ett spel där den under knappa förhållanden ges tillgång till förmåner så som inflytande över begränsade frågor eller individuellt lärande. Dessa forum har stor betydelse för människor som vanligtvis har mindre resurser och svagare nätverk (Ålund \& Reichel 2007). De bidrar till att utveckla nätverk, men också till att etablera social prestige. Spelen upprätthåller också finansieringsformer där civilsamhället med eller utan betalning till viss del tagit över tidigare offentlig verksamhet. Dessa forum är dock konsensusorienterade; de arrangeras av den lokala staten och bidrar hellre till att marginalisera protester och obekväma röster eftersom föreningarnas deltagande äger rum med ett viktigt förbehåll. Föreningarna befinner sig i en ojämlik beroendeställning till kommunen eftersom deras aktiviteter ofta är avhängiga den kommunala fördelningen av föreningsresurser. Demokratiberedningar, dialog- eller partnerskapsforum, arbets- och referensgrupper, förenings- eller integrationsråd riskerar vidare att institutionalisera en konkurrenssituation mellan föreningarna. I den urbana periferin har denna situation förstärkts genom att civilsamhällets organisering till följd av kontinuerliga förortspolitiska satsningar utvecklats i mycket nära relationer till den lokala staten (Denvall m.fl. 1997).

Nicholls och Uitermark (2017, s. 3If.) framhåller med exempel tagna från Los Angeles, Amsterdam och Paris att strategier för kontroll och styrning av civilsamhället inte endast handlar om att skapa självreglerande subjekt. Aktivister i civilsamhället kan trots statens styrambitioner uppträda synnerligen kritiskt och oföljsamt. Däremot kalibreras civilsamhällets aktörer från att företräda medlemmarnas intressen till 
att fokusera på att hantera sociala problem i samverkan med offentliga tjänstepersoner som kontrollerar spelreglerna. Samverkan bidrar på så sätt till att återskapa vissa föreningar som "goda” genom att de bidrar till att förverkliga statliga målsättningar, samtidigt som andra mer kritiska röster demoniseras och isoleras genom att nekas resurser. Statens styrning bidrar således till en "monokultur" i det civila samhället där kritiska element marginaliseras (ibid., s. 33). I anslutning till Nicholls och Uitermark menar vi att statens styrning bidrar till att föreningarna intar en defensiv roll i relation till pågående politik. Genom demokratiska spel bidrar styrregimerna till att styra civilsamhällets aktiviteter på stadsdelsnivå. Konflikter om exempelvis föreningsmedel dirigeras i sidled och blir föremål för besvär mellan föreningar i stället för att artikuleras hierarkiskt som en fråga om statens villkor för föreningslivet. Spelen bidrar dock till en "relativ tillfredsställelse" för deltagarna genom att lokalföreningar kan ansöka om ekonomiska medel och få uppskattning genom att arbeta med olika typer av sociala frågor i lokalområdet. Men på samma gång mystifierar detta spelets regler och tenderar att avpolitisera eventuellt motstånd. I fallstudien ska vi illustrera vad som händer när en kritisk röst bryter mot denna politiska ordning.

\section{Metodologiska överväganden}

Inspirationen till denna studie är den etnografiska "utvidgade fallmetoden" (Burawoy 199I) där studieobjektet är särskilda sociala situationer, det vill säga avvikelser, som behöver förklaras i förhållande till den institutionella kontexten ifråga. För denna studie handlar det om att på mikronivå försöka förstå organisationen Megafonens tillblivelse, aktiviteter och det bemötande som den fått från den lokala staten. Vidare avser vi att förklara detta i relation till den institutionella kontexten, i detta fall den senaste i raden av förortspolitiska stadsförnyelseprojekt. Det empiriska materialet i denna studie är baserat dels på fältstudier och intervjuer i Järva mellan 2005 och 20II, dels på etnografiska (direkt och deltagande observation) och processpårande (text- och dokumentanalys, intervjuer) undersökningar mellan 2012 och 20I7. Endast en begränsad del av det material

2. Studien är finansierad av Formas (projektnummer 250-20I3-I547). 
som har legat till grund för orienteringen av vår förståelse kring förortspolitiken, civilsamhället och den urbana periferin refereras i denna artikel. I etnografiska studier omfattar det empiriska materialet informellt underlag i form av personliga samtal, närvaro vid möten, deltagande i organisationens verksamheter, privata sammankomster och så vidare. Detta leder oundvikligen till frågor om forskarrollen och närhet respektive distans. $\mathrm{Vi}$ ansluter oss till den tradition inom etnografi som ser dialogen mellan forskare och beforskad som nödvändig för förståelsen av den särskilda sociala situationen i en given kontext. Det innebär att den distanserade och "neutrala" forskarrollen inte är något vi har eftersträvat eller ens ser som önskvärt i detta sammanhang. Samtidigt har vi inte heller haft som ambition att sträva efter den andra ytterligheten, där forskaren blir en del av eller går upp i den aktuella organisationen. En dylik total upplösning av gränser i relationen mellan forskare och beforskad tenderar också att osynliggöra makt och forskarens egna föreställningar och utgångspunkter (Wacquant 2009). Med vår utgångspunkt att dialog är nödvändig för denna studie har vi därför en slagsida mot närhet.

\section{Att göra kaos: Megafonen och Järvalyftet}

Vi återkommer nu till frågan om hur ungas aktivism kunde åstadkomma sådant "kaos" i ett kommunalt stadsutvecklingsprojekt. Händelserna återges i två delar. Den första handlar om Järvalyftets tillblivelse och redogör även för centrala logiker och tvetydigheter i detta kommunala utvecklingsprojekt. Den andra delen handlar om Megafonens tillblivelse och aktiviteter samt den turbulens de skapade i utvecklingsprojektet. I det första avsnittet diskuteras det offentligas närvaro som stadsförnyelseprojekt i termer av urbana styrregimer. I det andra resonerar vi om projektens samverkan och dialog med civilsamhället som ett demokratiskt spel.

\section{Järvalyftet som urban styrregim}

I Stockholm ger Socialdemokraterna år 2005 i uppdrag åt det kommunala aktiebolaget Svenska Bostäder (SB) att sjösätta en förnyelsesatsning för "ytterstaden". I Järva (Tensta, Rinkeby, Kista, Hjulsta, Akalla och Husby) med runt 70 ooo invånare kallas projektet "Järvalyftet" 
och har syftet att skapa "en positiv ekonomisk och social utveckling" (Boverket 20IO, s. 83). Detta ska ske genom att man åstadkommer en mer blandad bebyggelse avsedd att locka dit mer välbärgade invånare. Projektet finansieras bland annat genom att SB säljer bostadsbeståndet (I 200 lägenheter) i stadsdelen Hjulsta till ett privat fastighetsbolag för 600 miljoner kronor (Byggindustrin den I8 mars 2008). Initialt präglas Järvalyftets verksamhet inte av medborgardeltagande utan SB, som dominerar ägandet av fastigheter i Husby, formar ett eget planförslag för stadsmiljön och lägenhetsrenoveringarna. Insatserna motiveras utifrån en problembeskrivning som påtalar otrygghet i stadsdelen och som bygger på en enkätundersökning till de boende, där de ställer sig positiva till ombyggnationer (Fastighetsnytt I4 september 2007; SvD i8 oktober 2007). När Järvalyftet formellt drar igång presenterar SB sin plan där målet är att riva cirka I ooo lägenheter och områdenas gångbroar som utgör en del av trafiksepareringsstrukturen. Även om Stockholms finansborgarråd Annika Billström (S) (DN Io september 2006) under Järvalyftets uppstart deklarerar att den gamla förortspolitiken ska lämnas åt sitt öde till fördel för stadsutveckling baserad på "generella insatser till alla invånare" är Järvalyftet inte särskilt nydanande, förutom när det gäller omfattningen av ombyggnationerna.

Förortspolitik och dess olika satsningar är ingenting nytt i Järva. Staten initierade den så kallade Blommansatsningen och Storstadssatsningen och kommunen administrerade olika satsningar när stadsdelarna var byggda, och sedermera har statliga satsningar kompletterats med projekt som Ytterstadssatsningen och Stadsdelsförnyelse (Danielsson \& Hertting 2007). I de tidiga satsningarna var målet att komplettera brister i den sociala eller fysiska miljön och skapa sammanhållning bland de nyinflyttade (Urban 2005). På I980-talet fokuserade programmen på interventioner i den byggda miljön (Elander 1995; Denvall m.fl. 1997) och på 1990-talet var frågan om de nyanlända utlandsfödda invandrarnas "integration" på agendan i projekt som kallades för "åtgärder mot segregation" (Andersson m.fl. 20IO). En central aspekt har varit ambitionen att göra det civila samhället delaktigt $\mathrm{i}$ implementeringen av projekten genom "samverkan", "dialog", "underifrånperspektiv" och "partnerskap" (Urban 2005; Dahlstedt 2009). Järva- 
lyftet kan därför ses som upprättandet av en urban styrregim, det vill säga en procedur för hantering av problem och konflikter i stadsdelen. Genom förortspolitiska satsningar är projektets ambition att nå en koalition mellan berörda aktörer i ett givet område. I början var samverkansmålen emellertid nertonade i Järvalyftet. Det som kan liknas vid fabrikens ackordsspel, alltså demokratiska spel, rullades ut först då det uppstod konflikter kring planförslagen.

\section{Järvadialogen som spel och Megafonen som spelare}

Järvalyftet stöter tidigt på motstånd från Husbyborna. När planerna på rivningar och renoveringar med påföljande hyreshöjningar på upp till 75 procent presenteras, organiseras en protestmanifestation som samlar hundratals invånare 2007 (SR 29 november 2007; SvD 30 november 2007; $S v D 25$ april 2012). Lokalbefolkningens protester får relativ stor uppmärksamhet i medier samtidigt som Joakim Larsson (M) tilldelas positionen "Ytterstadsborgarråd". För att möta de boendes kritik initieras "Järvadialogen" där medborgardeltagande sätts i förgrunden. Denna nya giv inom Järvalyftet lanseras 2009 och kan ses som ett spel i Burawoys definition. Målet är att legitimera projektet genom att öppna för deltagande genom det som enligt utvärderingar (Lind 2016) och andra undersökningar (Loit 20I4, s. I72ff.; Hansson m.fl. 2013) har beskrivits som ytliga preferenskartläggande samråd. SB lanserar en informationskampanj om förnyelsearbetet och en lokal med namn "Järvadialogen” öppnas vid Husby torg. Öppettiderna är generösa och invånare kan ta del av "utställningar, möjlighet att lämna synpunkter, träffa ansvariga och möjlighet att delta i utvecklingen av Järva" (Svenska Bostäder 20I7). Järvabor rekryteras för att bemanna dialoglokalen och informera andra i stadsdelen om projektet. Enligt Järvalyftets projektledning resulterar dialogerna i att cirka 30 ooo synpunkter från Io ooo personer samlas in (ibid.). Stadsvandringar, "tvättstugemingel", gårdsfester, gemensamma utvärderingsprocesser och en rad olika projekt organiseras för att skapa en närmare relation till Husbyborna. Spelet kan ge fördelar för de enskilda deltagarna men har inte till syfte att säkerställa något inflytande över planförslagen. Vidare rullas det även ut riktade satsningar för att uppmuntra föreningar att delta i sociala verksamheter. Föreningslivet 
engageras i "miljöutbildningar" där de i utbyte mot ersättning arrangerar studiecirklar för medlemmar. Enligt projektledningen deltar 3300 individer i 369 studiecirklar (Stockholms stad 20I4, s. 32). I projektet "Järva rent och snyggt" arrangeras med "föreningsstädning som metod där fler än I5o föreningar städar områdets gemensamma ytor, parker och gångvägar” i utbyte mot ersättning (Spånga-Tensta 20I3; Rinkeby-Kista 2008). Hyresgästers delaktighet i planerna för lägenhetsrenoveringar formas genom samverkan med Hyresgästföreningen (HGF). Ett samråd med de boende kring olika tillval och kostnader för upprustning arrangeras inför renovering av varje fastighet. Arbetet resulterar bland annat i att hyresgästerna får möjlighet att välja mellan tre olika renoveringspaket med olika nivåer av hyreshöjning (Hyresgästföreningen 20I7; Stockholms stad 2015b, s. 23). Det demokratiska spelet arrangeras således på bred front genom en rad olika tekniker och nätverk.

Ytterligare en del av dialogarbetet berör unga i Husby och det är här Megafonen kommer in i bilden. År 2008 bestod föreningen av några kompisar i sena tonåren som träffats i stadsdelens ungdomsråd. Efter mordet på en jämnårig kamrat i Husby startar de en tidning för att motverka den stigmatiserade bilden av förorten. Ungdomarna uppmärksammas och engageras i Järvadialogen via HGF och deras liv förändras snabbt. De bjuds in att delta i panelsamtal för att ge sin bild av Husby i utbyte mot ekonomisk ersättning. De anställs som personal i Järvadialogen och hjälper till att rekrytera andra ungdomar i informationskampanjen. Ungdomarna får också gratis tillgång till en så kallad gårdslokal tack vare samverkan mellan SB och HGF.

Megafonens medlemmar är inledningsvis optimistiskt inställda till Järvalyftet. Dialogerna uppfattas som en möjlighet att göra stadsdelen bättre. Men de inser också att de både som enskilda individer och som förening går i god för Järvalyftet och med det uppkommer förväntningar från andra. Megafonens engagemang skruvas upp när de själva tar initiativet att uppmärksamma att unga mellan 17 och 25 år inte deltagit i de dialoger som genomförts. De ungas röster anses viktiga och Megafonen åtar sig att göra en egen studie som finansieras av SB. Under 20Io presenteras rapporten Att vara ung i Husby (Megafonen 20Io) där Megafonen genom fokusgruppsintervjuer sammanställer unga vuxnas erfarenheter 
och idéer kring vad som kan förbättras i stadsdelen. Tonen i rapporten präglas av samverkansvilja:

Lika mycket som alla synpunkter och åsikter i presentationen tillhandahålls för staden och bostadsbolagen, kommer de att få stor betydelse för Megafonens fortsatta arbete i Husby och Järva. Vi bjuder in kommunala, offentliga och privata aktörer att tillsammans med oss på Megafonen förverkliga de goda idéer som här finns att ta del av. (Megafonen 20IO, s. I.)

Flera av de frågor som lyftes i rapporten berör stora samhällsproblem, och Megafonen inser att de är svåra att göra något åt genom ett enda begränsat projekt. Men det finns också en del konkreta åtgärder, till exempel upprustning av idrotts- och aktivitetsplatserna, som är genomförbara på kort sikt. De unga aktivisterna understryker att de såg det som viktigt att det fanns lyhördhet för dessa förslag, särskilt då de vid detta skede investerat mycket prestige i dialogarbetet. Men att driva frågorna gentemot SB upplevde de som trögt. Relationen till Järvalyftets organisation blir sämre när Järvadialogens resultat efter ganska lång tid redovisas genom informationsmöten. Megafonen upplever återkopplingen från det omfattande dialogarbetet som en besvikelse. De anser att den är slarvigt genomförd, att det inte närvarade mycket folk på mötena och att SB:s nya förslag inte ändrats märkvärt från de ursprungliga förslagen 2007. Megafonen blir nu därför mer ifrågasättande:

Vi kritiserade dem. De kan inte säga en sak och sedan inte hålla det. De låter folks röster sväva runt. Man måste åtminstone få veta att om jag röstar för det här, går det igenom eller kommer det på prio ıo? Det var smågrejer som byggdes upp, men vi var fortfarande inte där att vi hade brutit med dom. (Megafonen IPI.)

Megafonen utvecklar kontakter med ett stadsdelsråd som bildats av äldre husbybor för att bevaka planerna för den byggda miljön. ”Nätverket för Järvas framtid" (NJF) som sedan byter namn till "Norra Järvas stadsdelsråd" mobiliserar individer och föreningar mot nedrustning av offentlig service i Husby. Förflyttningen av vårdcentralen till Kista blir en central händelse där Megafonen väljer att inte bara bevaka ungdomsfrågor utan också tar initiativ till en protestmanifestation i samverkan med NJF: "Vredens dag: från Tahrir till Husby". Dagen innan manifestationen har 
ungdomarna haft ett möte med Ytterstadsborgarrådet där de deklarerat sin ståndpunkt: hindra förflyttningen av vårdcentralen eller så träder vi ur samverkan med Järvalyftet. Borgarrådet menar att frågan ägs av landstinget och att kommunen inte kan göra mycket åt saken. Konflikten innebär ett slut på den formella samverkan mellan Megafonen och Järvalyftet.

\section{Kaos och bestraffning: att vägra spelet}

Under åren 20II-20I3 avlöser en rad konfrontativa interventioner varandra i Husby och ger under pågående dialogsatsning bilden av en stadsdel som präglas av konflikt mellan invånare och kommun. Den kaosartade situationen är ovanlig i svensk förortshistoria. Protester arrangeras emot privatiseringen av en lokal simhall och mot den nya strukturplanen som inte anses ha förändrats efter dialogen med de boende. Stockholms stad lägger för andra gången planerna att ändra strukturplanen åt sidan (Tunström 20I2). Den nedläggningshotade lokala mötesplatsen Husby träff ockuperas av Megafonen, NFJ och andra föreningar under parollen "Husby kräver respekt". Efter en veckolång ockupation ändrar SB planerna för att tillmötesgå föreningarnas krav.

Att vara "megafonare" uppfattas under denna period som att man är en kritisk och politiskt medveten aktivist som engagerar sig i förortens politik (León Rosales \& Ålund 20I7). En princip som Megafonen värnar efter att samverkan med Järvadialogen brutit ihop är att inte ta emot villkorade projektmedel från stat eller kommun. Strategin är ett medvetet val att hålla organisationen oberoende och bryter därför också mot den politiska ordningen:

Vi har samarbeten, men detta får inte villkora oss, vad vi vill skapa och inte skapa. Det är det som är viktigast. Reinfeldt får så klart om han vill ge oss tre miljoner, men om han försöker bestämma hur vi ska använda pengarna då blir det inget $[\ldots]$ (Megafonen IP2.)

Strategin står i kontrast till hur Megafonen ser på det traditionella civilsamhället i området. Så här resonerar en megafonare om relationen med andra föreningar: 
De etniska föreningarna har deltagit $\mathrm{i}$ våra möten men vi har inte samarbetat. De jobbar med sina egna ungdomar, vi har ett annat tänk. Många av de här föreningarna är säkert viktiga för området, men hålls tillbaka på grund av sitt ekonomiska beroende. Det finns många som får jättemycket pengar men inte gör så mycket. Sen kan man också kolla på deras verksamheter, vad de säger att de gör och vad de gör. Många gånger finns det ingen insyn i föreningarna. De kan också fungera som ett alibi för kommunen. Lite som en win-win situation. De är vänner med makten. (Megafonen IP2.)

De unga aktivisterna tar också klivet ut i den offentliga debatten. I flera debattartiklar i lokala och nationella tidningar går Megafonen ut i polemik mot Järvalyftet. Ungdomarna pläderar för en annan politisk ordning. I en debattartikel skriver de: "Ännu är det inte för sent för Järvalyftet att uppfylla sina högt ställda ambitioner. Men för detta måste Järvas medborgare omedelbart ges sina fulla demokratiska rättigheter att påverka de politiska beslut som formar våra bostadsområden" ( $D N_{31}$ mars 20I2). En megafonare skriver i en retrospektiv analys:

Under samma period som Järvalyftet har talat i storslagna termer om Järvas framtid, har vi som medborgare följt en samhällsutvecklings som varit den rakt motsatta. Sedan den första dialogen hölls våren 2009 har verksamheter som varit vitala för området lagts ner eller privatiserats, trots befolkningens eniga motvilja. Vi har i stället för utveckling av våra områden sett hur vårdcentraler, skatteverk, skolor, banker och postkontor har sålts ut eller försvunnit. Människor får det $\mathrm{i}$ och med detta allt svårare att utföra sina viktigaste vardagssysslor. Men framför allt förmedlas en bild av de boende att deras område än mindre viktigt än andra. (Al-Khamisi 20I5, s. I64.)

Samtidigt som Megafonen deltar och är drivande i lokala frågor i Husby har de en ambition att också mobilisera unga i andra förorter. Perioden 20IO-20I3 präglas av det som León Rosales och Ålund (20I7) kallar för en "folkrörelsernas renässans" i förorter runt om i Stockholm. Megafonen arrangerar folkbildningsträffar, mobiliserar ungdomar, ordnar gemensamma aktiviteter med andra organisationer i Stockholmsregionen och övriga landet samt driver opinionsbildning i medier, paneldebatter och egna forum. Det populära folkbildningscaféet "Harakat" blir en egen plattform för samtal om ungdomarnas levnadsvillkor. Under 2013 deltar föreningen i den mycket uppmärksammade protestkampanjen "Alby är inte till salu" i norra Botkyrka, som bildar en egen lokalavdelning av 
Megafonen. Ungdomarna arrangerar också manifestationer mot polismyndighetens interna utlänningskontroller och mot polisens övervåld efter myndighetens skjutning av en man i Husby, veckan innan upploppen bryter ut.

Uppståndelsen innebär också att ungdomarna stöter på motstånd från den urbana styrregimens aktörer. Från att ha börjat som Järvalyftets unga allierade blir Megafonen i sin nya konfrontativa roll en av dess hårdföra kritiker. En av megafonarna menar att de fătt "blodad tand" och med gott självförtroende tagit varje tillfälle i akt "att göra kaos" i Järvadialogens utåtriktade verksamheter genom att närvara på möten och framföra kritik (IPI). Att ställa sig utanför styrregimen för att öppet kritisera verksamheten bestraffas av både SB och Stockholms stad. För att återkoppla till frågan om självreglerande subjekt används här starkare tvångsinstrument från styrregimen för att disciplinera Megafonens aktiviteter. Det första steget blir att demonisera Megafonen som en odemokratisk organisation, vilket illustreras av nedanstående uttalande från Moderaterna. Uttalandet publiceras på Ytterstadsborgarrådets blogg och är ett svar på Megafonens debattartikel "Järvalyftet är ingen förebild" ( $S v D 4$ maj 20I2):

Dialogarbetet i Järva är en hörnsten i det pågående arbetet, tyvärr missuppfattar Megafonen syftet med dialogen. Dialog handlar om att ge och ta. Får man inte som man vill i en dialog är inte lösningen att ockupera en lokal och prata om att vissa boende i en stadsdel ska ha vetorätt i alla politiska beslut som fattas. Det demokratiska systemet fungerar inte så. Alliansen i Stockholm har fått förtroendet av väljarna att fortsätta förändringsarbetet i Järva och alla stadens stadsdelar. Det gör vi nu också, i dialog med boende, men det finns en representativ demokratisk ordning som de som inte tycker lika måste förhålla sig till. Det handlar om demokrati, inget annat. (Thulin 20I2.)

Citatet visar att Megafonen anses bryta mot "en representativ demokratisk ordning". I själva verket försöker de att påverka ett lokalt samverkansorienterat utvecklingsprojekt genom att framföra kritiska synpunkter. De kommunala aktörerna försöker därefter att begränsa Megafonens åtkomst till resurser inom kommunens rådighet. Föreningen har fått använda gårdslokalen i Husby utan kostnad. SB försöker under konflikten att dra tillbaka detta avtal. Bolaget hindrar också Megafonens lokalgrupper i Rinkeby och Vällingby/Hässelby att få tillgång till liknande 
avtal och lokaler (Hem \& Hyra $\mathrm{I} 6$ augusti 2012). Presstalesmanen på SB motiverar beslutet med att "man från bolagets sida är besvikna på hur Megafonen har utvecklats":

Vi upplåter lokaler hyresfritt åt hyresgäster som vill organisera sig och utveckla gården, det är kärnan. Sedan 2008 har Megafonen en sådan lokal, men sedan dess har deras verksamhet utvecklats till något annat [...] Vi känner oss väldigt svikna, de vill inte vara med i referensgruppen, inte delta i Husbyfestivalen, de har ockuperat en lokal illegalt. De har valt att stå utanför. Nu kräver de nya och ytterligare lokaler för sin verksamhet och anser att de inte ska betala hyra som alla andra. (Hem \& Hyra I6 augusti 20I2.)

I citatet ovan kan vi uttolka att SB:s talesperson förväntar sig att samverkanspartner ska följa spelets regler. Att ställa sig utanför och kritisera spelet som sådant, anses med andra ord som att man inte vill delta i "utvecklingen" av bostadsområdet. Megafonen har dock inte varit ensam i sin kritik av Järvalyftet. Utvärderingar och forskningsrapporter har återkommande kritiserat Järvalyftets upplägg och resultat (Loit 20I4; Lind 20I6). I journalistiska granskningar har projektet bland annat kallats för "luftslott" (SvD 24 april 20I2) och "förortsfiasko" (SvD 27 april 20I2).

Sammanfattningsvis menar vi att den häftiga kritik som Megafonen mötte måste förstås i relation till att de genom sitt avhopp och sin kritik ifrågasatte den politiska ordningen i sin stadsdel. Förortspolitiken formar urbana styrregimer och demokratiska spel som mystifierar maktrelationer och kalibrerar civilsamhällets aktiviteter till samförstånd hellre än konflikt. Turbulensen kring Megafonen bestod helt enkelt i att de vägrade att spela detta spel. I det avslutande avsnittet diskuterar vi varför det betraktas som en skandalös handling att ifrågasätta spelets regler.

\section{Sammanfattande diskussion: skandalös handling}

I denna artikel har vi argumenterat för att den politiska ordningen i marginaliserade områden kan förstås som en urban styrregim och att förortspolitikens funktioner förverkligas genom demokratiska spel. Att som deltagare "göra kaos" inom ramen för denna ordning innebär som vi ovan diskuterat inte några andra dramatiska aktiviteter än att ifrågasätta denna ordning, att ställa sig utanför eller att förmedla kritiska 
synpunkter som bryter med ett samförstånd mellan den lokala staten och det lokala civilsamhällets organisationer. Vi menar att det "kaos" som uppstår genom Megafonens konfrontativa handlingar synliggör den urbana styrregimen och dess ojämlika villkor. Genom förortspolitiska satsningar som Järvalyftet etableras procedurer för klagomålshantering genom delegering av ett marginellt inflytande över vissa beslut och begränsade resurser till civilsamhället. Järvadialogen kan ses som ett regimförankrande spel med syftet att legitimera den fastslagna handlingsplanen. Dialogen var inte utformad som ett deltagardemokratiskt beslutssystem utan snarare som en marknadsförande informationskampanj. De olika sociala projekten handlade till stora delar om att involvera föreningar i fördelningen av marginella resurser. Dessa offentligt initierade, ad hoc-organiserade och områdesbaserade förnyelseprojekt riktade till ett allt större antal förorter sedan 1980-talet formar över tid vad som närmast framstår som en permanent politik. Projekten har genom upprättandet av olika samverkansforum bidragit till att kalibrera det civila samhällets aktiviteter på ett sätt som neutraliserar konflikter utan att förändra den urbana maktordningen. Projekten bidrar således till att konservera en ojämlik urban ordning eftersom den försvagar förorternas möjligheter till gemensamt agerande för mer kvalitativ kollektiv konsumtion och drägligare levnadsvillkor.

Megafonens aktiviteter utgör i sammanhanget ett undantag. De väljer att mobilisera och bilda opinion mot förortspolitikens arrangemang eftersom gapet mellan projektets löften och verklighet blev uppenbara. Deras krav på ett meningsfullt deltagande demoniseras dock av kommunala aktörer som vidare försöker att exkludera ungdomarna. Megafonens tämligen odramatiska handlingar i samband med Järvalyftet kom därför att betraktas som "skandalösa", som odemokratiska och oacceptabla. För att förstå denna dynamik kan vi knyta an till ett resonemang som förts av Maud Eduards (2002, s. I5I). Hon frågar sig hur det kommer sig att vissa kvinnor tillåts organisera sig medan andra möter ett starkt motstånd och frågar sig om det finns handlingar som är "förbjudna" för kvinnor. Det är inte kvinnors krav som stöter på motstånd, menar Eduards, utan den "kollektiva handlingen i sig" som utmanar konventioner och normer kring "vad kvinnor får göra och inte göra”. Eduards tillför att den 
mest förbjudna handlingen är den feministiska organisering som synliggör "män som en politisk kategori" och som försöker förmå dem att ta ansvar i termer av kön och makt. Om vi knyter detta resonemang till Megafonen, så kan vi konstatera att de under de pågående demokratiska spelen artikulerade krav om politisk förändring och en annan politisk ordning än den etablerade i deras bostadsområde. Anledningen var att de efter deltagandet inte upplevde att de gynnades av arrangemangens former och resultat. I linje med Eduards argument synliggjorde de därför att den politiska ordningen inte handlade om att styra stadsdelen emot en demokratisk och jämlik framtid, utan om att det i förlängningen skulle leda till att den ojämlika urbana ordningen konserverades. För ett ögonblick blev därför den politiska ordningen i stadsdelen transparent: kommunförvaltning och bostadsbolag stod som kejsaren, i kejsarens nya kläder, nakna - i detta fall inför en handfull ungdomars krav på att få delta i utvecklingen av bostadsområdet. Megafonens förbjudna handling var för det första att de överskred det handlingsutrymme som var möjligt för vad förortsbor får göra i ett samverkansprojekt. Och för det andra bidrog de till att politisera den politiska ordningen genom att synliggöra regimens spelregler som ojämlika i ljuset av det gap som fanns mellan löfte och verklighet.

Genom denna intervention dömdes föreningen ut som "förortsgäng" utan respekt för demokratiska spelregler, som Abdul Fattah skriver i det inledande citatet. I själva verket står det inom en samförståndsinriktad och förment demokratisk dialog inte andra medel till buds för missgynnade grupper att uttrycka sin kritik annat än genom att störa den ordning som dialogens administratörer arrangerat (Young 2000). Även om den dialoginriktade demokratin kan möjliggöra rättvisa för underordnade grupper kan dess spelregler också skapa maktordningar som ytterligare bidrar med dominans och förtryck. Grupper som likt Megafonen upplever att villkoren och agendan för dialog missgynnar deras intressen kan i ett sammanhang där "resonlighet" framhävs som en dygd enkelt avfärdas som "oresonabla" och därför odemokratiska (ibid.). Det var också precis detta som inträffade inom ramen för ungdomarnas engagemang i Järvalyftet. Blott genom att vägra att spela med i det demokratiska spelet och kritisera dess spelregler orsakade Megafonen detta "kaos". 
Japhy Wilson och Erik Swyngedouw (2014) har argumenterat för att jämlikhetsivrande och demokratiska krav inom ramen för en avpolitiserad och förment "demokratisk" ordning framstår som skandalösa utifrån rådande normer om vilken politisk ordning som är möjlig att skapa. Essensen i det skandalösa består då i att ställa egalitära och demokratiska krav som ligger bortom den etablerade ordningen. Megafonen har som sagt inte avslöjat djupare hemligheter i förortspolitikens sätt att fungera och framförde heller inte heller skandalösa fakta angående Järvalyftets verksamhet. De sällade sig snarare till en våg av kritik som riktats mot olika demokratiska spel i städer runt om i världen. "Den fundamentala motsägelsen i demokratiska innovationer", för att exempelvis relatera till två av dessa kritiker, Gianpaolo Baiocchi och Ernesto Ganuza (2017, s. 50), "är att de bjuder in till deltagande för att debattera det gemensamma bästa men rustar inte vanliga medborgare med makt att avgöra dess resultat”. Megafonens krav om en annan demokratisk ordning än den som rullades ut av Stockholms stad och dess bostadsbolag framfördes under pågående spel, där medborgare involverades i eventliknande spektakel utan att ges egentlig möjlighet att förändra de administrativa procedurerna för utvecklingen av stadsdelen. Det skandalösa i Megafonens handling bestod just i synliggörande av förortspolitikens ojämlikhet, såsom den upplevdes både inifrån och utanför den regim som uppfördes genom Järvalyftet. I en samtid där förortens boende samtidigt både ses som passivt (icke-deltagande) och aktivt (extremistiskt) odemokratiska begick Megafonen en skandalös handling: man krävde att få delta. Det anstår både civilsamhällets organisationer och de offentliga projektens demokratiivrande arrangemang att hantera denna spänning i de framtida regimer som redan i dag är under konstruktion. 


\section{Referenser}

Abdul Fattah, Nabila (20I4) "Varför så rädda för demokratin”, ETC 27 maj 2014. URL: https://www.etc.se/ledare/varfor-sa-radda-demokratin (28 mars 20I8)

Al-Khamisi, Rami (2015) "Dialogen som blev en monolog", i Lindholm, Teresa, Oliveira e Costa, Sandra \& Wiberg, Sofia (red.) Medborgardialog. Demokrati eller dekoration? Stockholm: Arkus.

Andersson, Roger, Bråmå, Åsa \& Holmqvist, Emma (2010) "Counteracting segregation: Swedish policies and experiences", Housing Studies, 25, 2, s. 2372-2356. DoI: https://doi.org/10.1080/02673030903561859

Baiocchi, Gianpaolo \& Ganuza, Ernesto (2017) Popular democracy. The paradox of participation. Stanford: Stanford University Press.

Boverket (2010) Socialt hållbar stadsutveckling - en kunskapsöversikt, rapport från Boverket. URL: https://www.boverket.se/globalassets/publikationer/dokument/20Io/socialthallbar-stadsutveckling.pdf (28 mars 20I8)

Burawoy, Michael (1979) Manufacturing consent. Changes in the labor process under monopoly capitalism. Chicago: University of Chicago Press.

Burawoy, Michael (1985) The politics of production. Factory regimes under capitalism and socialism. London: Verso.

Burawoy, Michael (199I) Ethnography unbound. Power and resistance in the modern metropolis. Berkeley: University of California Press.

Burawoy, Michael (1992) "Arbetsprocessen som spel”, Idéer om arbete. Stockholm: Tiden.

Burawoy, Michael (2012) "The roots of domination. Beyond Bourdieu and Gramsci", Sociology, 46, 2, s. 187-206.

DOI: https://doi.org/IO.II77/0038038511422725

Castells, Manuel (1977) The urban question. A Marxist approach. London: Arnold.

Cockburn, Cynthia (1977) The local state. Management of cities and people. London: Pluto Press.

Dahlstedt, Magnus (2009) Aktiveringens politik. Demokrati och medborgarskap for ett nytt millenium. Malmö: Liber.

Danielsson, Marianne \& Hertting, Nils (2007) Utvärdering av Stadsdelsförnyelsen. Slutrapport från Mälardalens utvärderingsakademi, rapport från Mälardalens högskola. URL: http://uu.diva-portal.org/smash/get/diva2:39383/FULLTEXToI.pdf (28 mars 2018)

Denvall, Verner m.fl. (1997) Välfärdens operatörer. Social planering i brytningstid. Umeå: Boréa i samarbete med Byggforskningsrådet.

Dikec, Mustafa (2007) Badlands of the republic. Space, politics, and urban policy. Oxford: Blackwell.

Eduards, Maud (2002) Förbjuden handling. Om kvinnors organisering och feministisk teori. Malmö: Liber ekonomi.

Elander, Ingemar (1995) "Policy networks and housing regeneration in England and Sweden", Urban Studies, 32, 6, s. 913-934. DOI: https://doi.org/I0.IO80/004209895500I27I7 
Franzén, Mats, Hertting, Nils \& Thörn, Catharina (2016) Stad till salu. Entreprenörsurbanismen och det offentliga rummets värde. Göteborg: Daidalos.

Gustafson, Per \& Hertting, Nils (20I7) "Understanding participatory governance. An analysis of participants' motives for participation", The American Review of Public Administration, 47, 5, s. 538-549. DoI: https://doi.org/IO.II77/0275074015626298

Harvey, David (1976) "Labor, capital, and class struggle around the built environment in advanced capitalist societies", Politics \& Society, 6, 3, s. 265-295. DoI: https://doi.org/Io.II77/00323292760060030I

Hansson, Karin, Cars, Göran, Ekenberg, Love \& Danielson, Mats (2013) "The importance of recognition for equal representation in participatory processes. Lessons from Husby", Footprint, I3, s. 8I-98. DoI: https://doi.org/I0.7480/footprint.7.2.77I

Hyresgästföreningen (2017) Från protest till samråd, film producerad av Hyresgästföreningen.

URL: https:/www.hyresgastforeningen.se/stod-och-rad/renovering-ochupprustning2/paverka-vid-upprustning/ (8 augusti 20I7)

Kings, Lisa (2011) Till det lokalas försvar. Civilsambället $i$ den urbana periferin. Lund: Arkiv.

Kugelberg, Clarissa \& Trovalla, Eric (2015) Samverka ochleller styra. Att praktisera medborgarinflytande i planering och beslutsfattande. Göteborg: Makadam.

Lefebvre, Henri (I99I) The production of space. Oxford: Basil Blackwell.

León Rosales, René \& Ålund, Aleksandra (2017) "Renaissance from the margins. Urban youth activism in Sweden", i Ålund, Aleksandra, Schierup, Carl-Ulrik \& Neergaard, Anders (red.) Reimagineering the nation. Essays on twenty-first-century Sweden. Frankfurt am Main: Peter Lang.

Lind, Jan-Erik (20I6) Järvalyftet 2006-20I4. Hur kan Järvalyftet förstås?, presentation vid konferensen Lärdomar Järva, 25 maj 2016 i Kista. Arrangerad av Stockholms stad.

Loit, Jon (20I4) En stad i världsklass - hur och för vem? En studie om Stockholms sociala stadsplanering. Uppsala: Uppsala universitet, Kulturgeografiska institutionen.

Mayer, Margit, Thörn, Catharina \& Thörn, Håkan (red.) (20I6) Urban uprisings. Challenging neoliberal urbanism in Europe. London: Palgrave Macmillan.

Megafonen (2010) Att vara ung i Husby. Åsikter och synpunkter från I8-25 åringar, rapport från Megafonen.

URL: http://jarvadialogen.episerverhosting.com/Documents/Megafonen-rapport2Isep-IIO.pdf (3 september 20I7)

Nicholls, Walter J. (2003) "Poverty regimes and the constraints on urban democratic politics", European Urban and Regional Studies, Io, 4, s. 355-368. DOI: https://doi.org/10.1177/09697764030104005

Nicholls, Walter J. \& Uitermark, Justus (2017) Cities and social movements. Immigrant rights activism in the US, France, and the Netherlands, 1970-20I5. Chichester: Wiley.

Olsson, Sören \& Törnquist, Anders (2009) Förorten. Insatser och utveckling under 40 år. Stockholm: Arkitekternas forum för forskning och utveckling (Arkus). 
Rinkeby-Kista (2008) Föreningsstäd $i$ samverkan över Järvafältet, tjänsteutlåtande 7 maj 2008. DNR:SDor 300-236-2008, DNR:SD03099-228/o8. Stockholms stad, Rinkeby-Kista Stadsdelsförvaltning.

Spånga-Tensta (2013) Järva rent och snyggt, promemoria Stockholms stad, Spånga-Tensta Stadsdelsförvaltning 13 februari 2013.

Stockholms stad (2014) Hållbara Järva. Slutrapport till Boverket, rapport från Stockholms stad.

URL: https://www.boverket.se/contentassets/847d62f86bca4e97b32c51099ffb2523/

hallbara-jarva.pdf (28 mars 20I8)

Stockholms stad (20I5a) Skillnadernas Stockholm. Kommissionen för ett socialt hållbart Stockholm.

Stockholms stad (2015b) Hållbara Järva. Samlade erfarenheter frän Svenska Bostäders renovering i Akalla, Husby och Rinkeby 20I0-2014, rapport från Stockholms stad.

URL: http://www.stockholm.se/PageFiles/169740/H\%c3\%asllbara\%20 J\%c3\%a4rva\%2O-\%20rapport\%2osamlade\%2oerfarenheter.pdf (28 mars 20I8)

Stone, Clarence Nathan (1989) Regime politics. Governing Atlanta, 1946-1988. Lawrence: University Press of Kansas.

Svenska Bostäder (20I7) Välkommen till Järvadialogen - informationscentrum för Järvalyftet, från Svenska Bostäders hemsida för Järvadialogen.

URL: http://jarvadialogen.episerverhosting.com/Jarvadialogen/ (8 augusti 20I7)

Tahvilzadeh, Nazem (2015) "Understanding participatory governance arrangements in urban politics. Idealist and cynical perspectives on the politics of citizen dialogues in Göteborg, Sweden", Urban Research \& Practice, 8, 2, s. 238-254. DOI: https://doi.org/I0.1080/17535069.2015.1050210

Thulin, Magnus, (20I2) Megafonen, demokrati och främlingsfientlighet, bloggpost 7 maj 20I2, Moderaterna Stockholm.

URL: http://moderaterna.net/joakim/author/magnust/ (8 augusti 20I7)

Tunström, Moa (20I2) "Promenadstaden protest mot miljonprogrammet", Tidskriften Arkitektur, 3, s. I4-15.

Urban, Susanne (2005) Att ordna staden. Den nya storstadspolitiken växer fram. Lund: Arkiv.

Urban, Susanne (2018) Integration och grannskap. Hur kan staden hålla samman? Lund: Studentlitteratur.

Wacquant, Loïc (2009) "The body, the ghetto and the penal state", Qualitative Sociology, 32, I, S. IOI-I29.

DOI: https://doi.org/I0.I007/sIII33-008-9II2-2

Wijkström, Filip \& Lundström, Tommy (2002) Den ideella sektorn. Organisationerna $i$ det civila sambället. Stockholm: Sober.

Wilson, Japhy \& Swyngedouw, Erik (20I4) "Insurgent architects and the spectral return of the urban political", i Metzger, Jonathan, Allmendinger, Philip \& Oosterlynck, Stijn (red.) Planning against the political. Democratic deficits in European territorial governance. London: Routledge.

Young, Iris Marion (2000) Inclusion and democracy. Oxford: Oxford University Press. 
Ålund, Aleksandra \& Reichel, Isak (2007) "Mellan marknad och volontär aktivism. Arbete för social inkludering bland svenska medborgarsammanslutningar bildade på etnisk grund”, i Dahlstedt, Magnus (red.) Utbildning, arbete och medborgarskap. Strategier för social inkludering i den mångetniska staden. Umeå: Borea.

\section{Medier och tidningsartiklar}

Aftonbladet I4 maj 20I4, "De får skulden för upploppen i Husby". Byggindustrin I8 mars 2008, "Einar Mattsson köper hela Hjulsta".

Dagens Nyheter Io september 2006, "Vi satsar miljarder på att rusta upp förorterna".

Dagens Nyheter 31 mars 20I2, "Järvas medborgare måste få påverka".

Dagens Nyheter 4 juni 2013, "Megafon med oklar röst".

Fastighetsnytt i4 september 2007, "Ur ett strategiskt perspektiv".

Hem \& Hyra I6 augusti 20I2, "Inga fler hyresfria lokaler för Megafonen".

Svenska Dagbladet 18 oktober 2007 , "Boende vill lyfta Järva".

Svenska Dagbladet 30 november 2007, "Protester mot Järvalyftet".

Svenska Dagbladet 24 april 20I2, "Lyftet ett luftslott för Järvaborna".

Svenska Dagbladet 25 april 20I2, "Järvafältet kan bli som Central Park".

Svenska Dagbladet 27 april 20I2, "Förortsfiasko för flera miljoner".

Svenska Dagbladet 4 maj 20I2, "Järvalyftet är ingen förebild".

Sveriges Radio 29 november 2007, "75-procentig hyreshöjning hotar Husby".

\section{Intervjuer}

Megafonen intervjuperson I, 2I januari 20I5, inspelat samtal 86 minuter.

Megafonen intervjuperson 2, I3 november 20I2, inspelat samtal 83 minuter. 


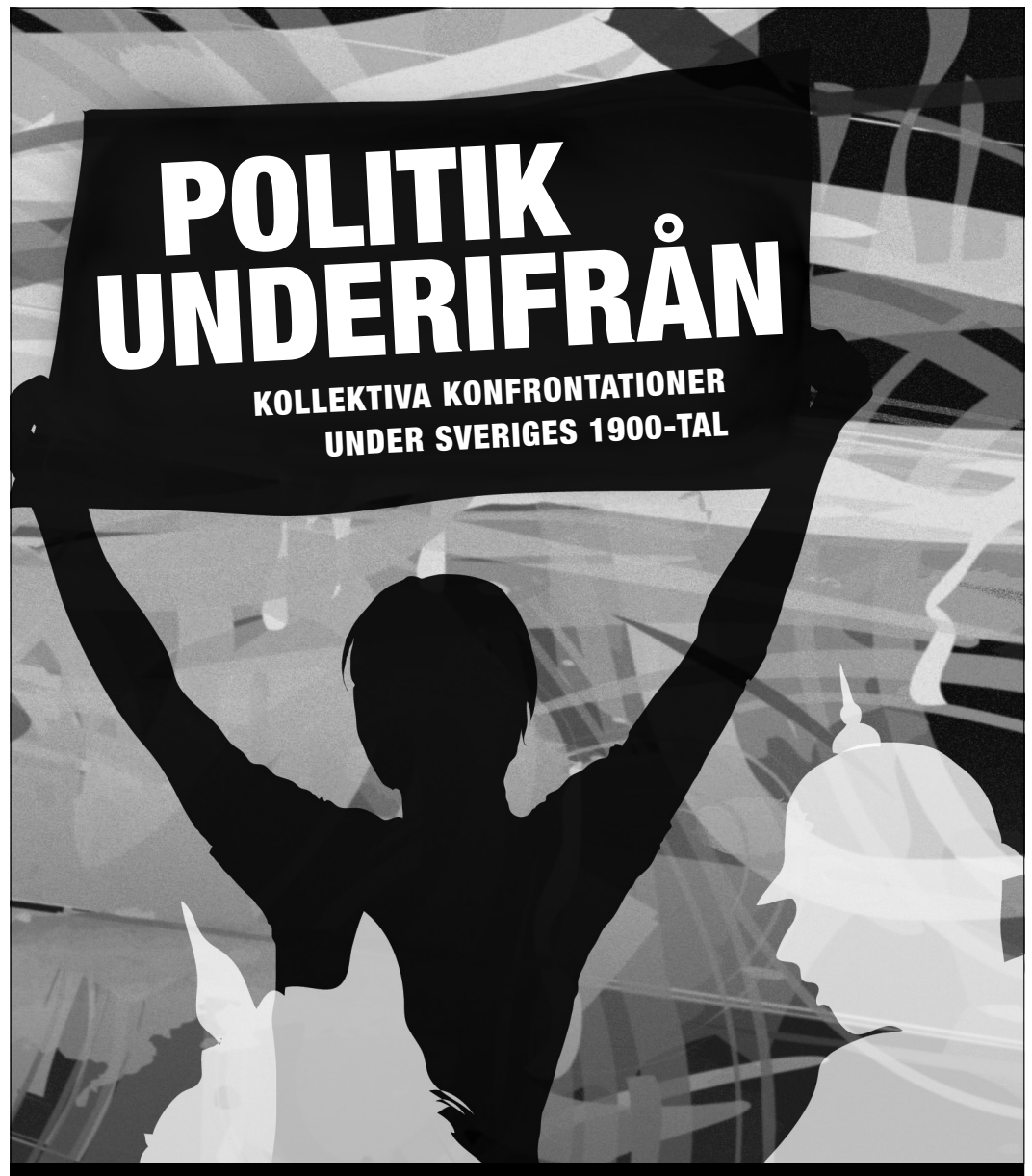

I POLIIK UWDERIFRÅN skriver historiker och samhällsvetare om politiska och sociala konflikter i 1900-talets Sverige då människor har brutit mot den dominerande politiska kulturens normer för hur man får göra politik och vilka som får delta i politiska processer. Från rösträttsstriden i början av seklet, över gatukravaller, vilda strejker och den gryende miljörörelsens kamp, till konflikter om vem som har rätt att använda det urbana rummet åren efter murens fall.

Andrés Brink Pinto \& Martin Ericsson (red.), Arkiv förlag, 216 sidor

\section{"LÄS MER OM BOKEN PÅ WWW-ARKIWNUW}




\section{Susanne Urban}

\section{Att ordna staden}

Den nya storstadspolitiken växer fram

Staden som hot eller löfte? I Sverige har den etniska boendesegregationen i storstäderna gått från att vara en rättvisefråga till att ses som ett hot mot den sociala sammanhållningen och välfärdsstatens demokratiska värden. Den sociala integrationens löfte förväntas bli infriat i grannskapet, där delaktighet skall skapas och orättvisor upplösas. Susanne Urban granskar den svenska storstadsutvecklingen, grannskapsenheterna, planerarna, utredarna, kommunaltjänstemännen, politikerna och deras olika försök att komma åt dagens etniska - bostadssegregation genom den "nya" storstadspolitiken och dess objekt: Förorten.

Arkiv förlag, 224 sidor 